\title{
ENHANCING USERS' COMFORT IN EXISTING UNIVERSITY LIBRARIES IN EGYPT THROUGH DAYLIGHT STRATEGIES
}

\author{
Samar Bakr ${ }^{\text {a }}$, Gehan Nagy ${ }^{\text {** }}$ \\ ${ }^{a}$ Student at the British University in Egypt (BUE), Faculty of Engineering, Architectural \\ Engineering Department, El Sherouk City, Egypt \\ ${ }^{\mathrm{b}}$ Associate Professor at the British University in Egypt (BUE), Faculty of Engineering, \\ Architectural Engineering Department, El Sherouk City, Egypt
}

\begin{abstract}
University libraries are one of the most important places that offer knowledge, services and a suitable study environment. A well-designed library space can have a great impact on students' performance and social behavior. Daylighting is a controlled tool that affects the perception, visual, psychological comfort, and behavior of library users. However, many of the current university libraries in Egypt lack the presence of efficient daylighting strategies and without consideration of how daylight affects students' comfort. The group study area, social gathering space, and private reading space are three different areas in the academic library with different usage and different daylight distribution. This research aims to identify a set of design strategies for using daylight to enhance users' psychological condition, interaction with the surrounding, and visual comfort in private reading space, group study space, or a social space, in the university libraries. The research method will be based on four phases starting with analyzing the different strategies of daylight in a space. Followed by discussing the aspects of daylight that influence human visual and psychological condition. Then, analyzing each space in the academic library by understanding its different usage, daylight distribution, and effect on student perception and comfort. Finally, deducting a design method that will be used a checklist (matrix) to identify different sittings of daylight strategies in different library spaces. The expected result will be deducted from the design matrix to identify a set of efficient daylight strategies for selected spaces in academic libraries to
\end{abstract}

enhance user's visual comfort, psychological condition, and interaction with the surrounding.

Keywords: Daylighting strategies, User's comfort, University libraries, Visual comfort, Psychological comfort.

\section{Introduction}

University libraries are considered the most respected type of buildings for higher education and learning system (Chakravorty,1954). Academic libraries are very important, as they allow students to have access to study information, data sources, and other services (Klain Gabbay \& Shoham, 2019). University libraries are one of the most important places that offer knowledge, services, study environment and social life (Ludwing and starr, 2005). Efficiency is considered more important in university libraries than any public library. For students the design of libraries affects the ability of using the library in anytime. Therefore, well-designed university libraries are being used not only for studying, reading and accessing to digital sources but also as social gathering places (Cunningham, Heather V \& Tabur, Susanne, 2012). Interior spaces of a library such as private reading areas, crowded reading halls and social gathering spaces could change the student's education life and perspective to the whole university (Cunningham, Heather V \& Tabur, Susanne, 2012).

Daylighting is one of the important features that can have an impact on the usage of the library spaces (Gregg D. Ander, 2003). Daylight creates an atmosphere of quietness and visual comfort in order to psychologically associate the library user 
with the space they occupy (Perera \& Swaris, 2017). Daylighting openings make it possible to link building users to the outside world and without this relation the user feels something is lacking in the space (Phillips, 2004). For decades, unforgettable library spaces have been distinguished by natural light, illuminating volumes and surfaces while providing glare-free light in reading spaces. Hence, daylight is one of the key architecture tools that could be controlled to enhance the users' visual and psychological comfort in libraries (Sufar et al., 2012). Through taking in consideration the design tools that affects the user's mood, comfort and motivation and implement those features in an efficient way to reach the user's satisfaction.

The amount of daylight in a space can have a huge influence on the human's psychological conditions (Perera \& Swaris, 2017). It is essential to use daylight in an efficient manner in library buildings as it can influence users' mood, reading, productivity, and visual and psychological condition (Cuttle, 2011). Therefore, the purpose of this research is to understand the relationship between daylight and user's comfort and how the visual and psychological comfort is affected by daylight in different academic library spaces.

\section{Daylight Strategies}

Daylight is one of the quality-enhancing features and controls how long someone stays in a space (Kilic \& Hasirci, 2011). Daylighting elements as the good lighting, the size of a window and the visibility have an important effect on the user's psychological satisfaction (Hourani and Hammad, 2012). Daylight creates a connection between the indoor and outdoor environment which make it more comfortable to have a space with efficient daylighting (Gregg D. Ander, 2003). To have an efficient daylight in a space, it is not only about adding skylights or large windows but also need detailed integration of daylight design strategies which are heat gain, variations in light availability and glare control in the building (Ander, 2016). Some design strategies must be taken into consideration to achieve successful daylighting into a building such as building form and orientation, shading devices, interior finishes, glazing material and opening size and spacing. Therefore, to achieve an efficient daylighting into a space it is not only about providing enough daylighting but also about how to minimize its undesirable effects.

\subsection{Building Orientation}

The building orientation is very important to control the amount of heating, cooling and daylight entering the building (Abdultawab, 2017). For example, if the long side of the building is oriented towards the east-west side then, the building will join a passive amount of heating or cooling on a seasonal basis (Guzowski, 2000). It is favorable to orient most of the north-south glazing, with maximum exposure to daylight that is easier to control

(figure 1).

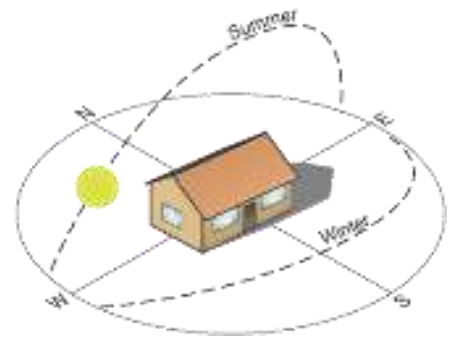

Fig. 7: Building Orientation (Abdultawab, 2017)

\subsection{Building Form}

Buildings footprints are different, and each form has different way of penetrating daylight into the building (Qahtan, 2017). which could be long and narrow, square, L-shape, U-shape or linear and thin (Figure 2). To maximize daylight into the building, Long and narrow footprints are better than square one. Buildings can be arranged as a series of wings to reduce the need 
for land while still allowing daylight access

(Peter Tregenza, Michael Wilson, 2011).
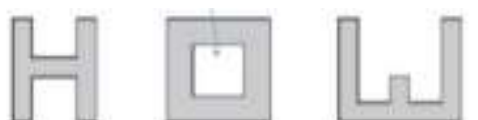

Fig. 8: Building Footprints (Qahtan, 2017)

\subsection{Opening Type and Location}

Opening are the way to have an efficient daylight in the building as it controls the amount of heat, solar, natural light and light intensity in the indoor space (Peter Tregenza and Michael Wilson, 2011). Opening location will impact daylight penetration in the room and will determine the amount of useful daylight. Window location should also consider the relationship between the occupants ' view to the outside and eye level (Reinhart, 2014).

- Vertical windows: to allow optimum daylight in a room the vertical windows should be wide and placed at the top of the wall (Peter Tregenza and Michael Wilson, 2011). Vertical windows on the wall are three times less effective compared to horizontal roof lighting (Figure 3). According to Kashyap (2017), Baffles and Light shelves allows diffusive daylight and avoid glare (Figure 4).
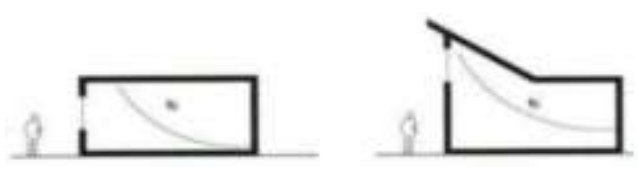

Fig. 9: Light Distribution through vertical (Kashyap, 2017)

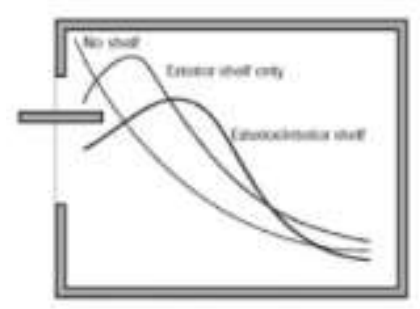

Fig. 10: Vertical Window with Shelves (Qahtan, 2017)

Skylight Opening: skylight should be sloped, horizontal or domed (Figure 5) and recommended to have a splayed opening on the roof to reduces heat gain, glare and allows indirect and deeper sunlight into the room but only effective on the building's top floor (Figure 5) (Kashyap,

2017).

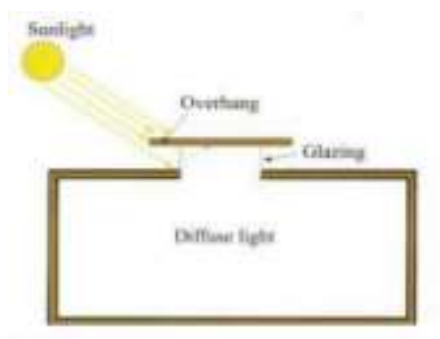

Fig. 6: Monitor Skylight (Kashyap, 2017)

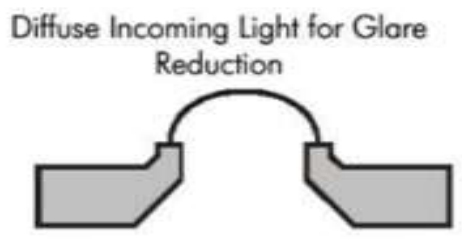

Fig. 5: Skylight with Splayed Opening (Kashyap, 2017)

- Clerestory windows: reduces glare and allows natural ventilated daylight in the room. The window always located at a high away from the eyelevel (Figure 6). Sawtooth lighting reduces heat gain by 


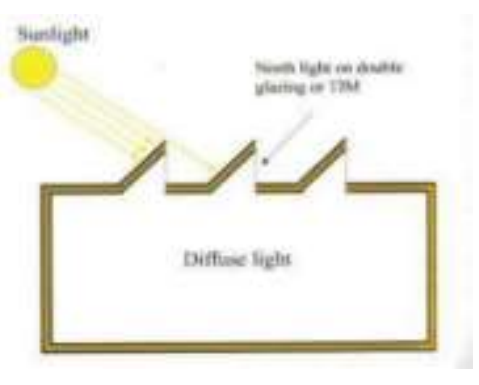

\subsection{Glazing}

Fig. 12: Clerestory Windows (Qahtan, 2017)

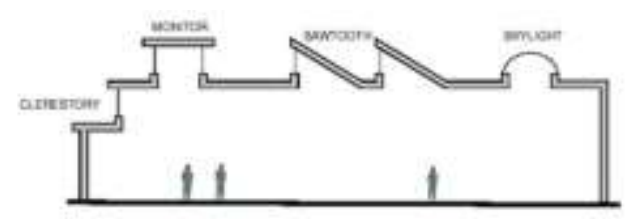

Fig. 11: Different types of Roof Openings (Qahtan, 2017)

Glazing allows natural daylight to enter the building, but also allows unnecessary solar gains in summer and winter weather. Glazing ratios are recommended to be between 25 to $50 \%$ on the external side of the space that needs daylight (Duxbory, 2013). The daylight levels and thermal comfort depends on the type of glazing used on the opening. Thus, the best type of glazing is the triple glazing as it allows more thermal comfort in the building (table 1). On the other hand, double glazing, tinted or reflective glazing minimize the transmission of daylight into the building with more solar transmission (Gregg D. Ander, 2003).

Table 1. Glazing Types (Duxbory, 2013)

\begin{tabular}{r|r|r}
\hline $\begin{array}{c}\text { Window } \\
\text { specifications }\end{array}$ & $\begin{array}{r}\text { Daylight } \\
\text { transmission } \\
(\%)\end{array}$ & $\begin{array}{r}\text { Solar } \\
\text { transmission } \\
(\%)\end{array}$ \\
\hline Single glazing & $88 \%$ & $83 \%$ \\
\hline $\begin{array}{c}\text { Double } \\
\text { glazing }\end{array}$ & $77-80 \%$ & $65-70 \%$ \\
\hline
\end{tabular}

tilting the roof opening towards the north (Qahtan, 2017).

\begin{tabular}{r|r|r}
\hline $\begin{array}{r}\text { Tinted double } \\
\text { glazing }\end{array}$ & $29 \%$ & $39 \%$ \\
\hline Triple glazing & $70 \%$ & $40-60 \%$ \\
\hline
\end{tabular}

\section{Daylight and Human Comfort}

According to Keith Slakter (1985), internal environment human comfort is affected by many different factors such as, psychological factors, physical factors and personal factors. The productivity and comfort of the users are influenced by the lighting condition factors in the interior environment (Harsirci, 2011). Users' psychology is affected by adaptive visual comfort and lower levels of illumination produced better emotional responses to adapt the standard light level (Fridell Anter, 2014). The light intensity, the visual qualities, ventilation, temperature and spatial organization of the space are some of the factors that affects the human visual and psychological comfort.

\subsection{Glare}

A good design of daylight will allow large amounts of glare inside the building (Gregg D. Ander, 2003). The variation of light within our environment may influence the occupant's visual comfort and performance. Daylight glare are caused by several sources; such as, bright sky, the clouds and sun reflective surfaces (Rea, 2000).

- Disability glare: this type occurs when glare sources of high luminance such as; the sun and reflection of the sun are in the interior environment. It influences the human visual comfort as it reduces the visual performance and visibility of the eye (Rea, 2000).

- Discomfort glare: is influenced by all the visual components in the environment such as; the windows, 
reflections, interior surface and external surroundings. This type of glare causes an after effect on the user in form of fatigue, headaches. Also, may cause distraction or irritating in the eyes (Rea, 2000).

\subsection{Temperature}

Glass openings allow the solar heat to enter the indoor environment which affects the indoor temperature, especially when sitting near a window (Grimaldi et al., 2008). The rise in temperature of an indoor environment causes an increase in blood pressure and decrease of the user's speed of reading and allowing the user to feel discomfort in the space (Dean, 2005).

\subsection{Light Intensity}

If the levels of light are too high or too low, then it will not be suitable in the environment and will influence the human visual comfort (Boyce et al., 2003). The roof windows are better in integrating daylight into the space as it spreads the light intensity in all direction not only in on spot (Dean, 1998). When the degree of daylight intensity is the greatest it may cause the eyes to go blind because of the brightness or stain the eyes because it is too dark. Therefore, the location of the window and the material used, have an impact on the degree of daylight entering the room which provide daylight in all directions and minimize its intensity as it has a bad influence on the eyes and human's concentration also may cause distraction and visual discomfort (Rea.2000).

\subsection{Spatial organization}

Students undertake a variety of activities during the writing process, which require different spaces, furniture and tools (Foster \& Gibbons, 2007; Twait, 2009). The seating configuration affects the occupant's quality in the reading function, speed and overall efficiency of the visual task (Fontoynont and Escuyer, 2001). According to Charrette design experiment at the
University of Rochester, curtain wall windows were integrated into a redesigned library. As a result, the arrangement of the furniture was changed to place tables by these windows for group work. Students concluded that they would spend most of their time working in teamwork and therefore, wanted to be located in the ideal window zone of the building as it affects the quality in the reading, speed and overall efficiency of the visual task. (Foster \& Gibbons, 2007).

\section{Daylight and Academic Libraries}

University libraries are considered the most respected type of buildings for higher education and learning system (Chakravorty,1954). According study conducted by J. Malenfant, (2017), to investigate the academic library impact on student learning and success, each space in the library either social gathering, crowded reading area or private reading rooms, require different spaces and design and both are evenly important in the learning and social life of the student. Therefore, the library is the perfect place for the Students who want to build relationships with other students, see, interact and communicate with each other (Brown et al., 2017). Shill and Tonner (2004) agreed that for redesigning library usage, natural light was one of the strongest determining factors. As the traditional library spaces can modulate the student's university experience with higher education values and objectives by active resonance or simultaneous awareness or some other means.

As a result, the placement of the windows and arranging the furniture according daylight plays an important role in the users' visual and psychological comfort for reading, studying, and social interaction. Which changes the user's preference and comfort in each space according to the usage (Klain Gabbay \& Shoham, 2019).

\subsection{Academic Library Spaces and Lighting Needs}

Reading in a library is the main function. While libraries have recently become increasingly digital, the focus on books and reading is still 
ongoing (Brons, 2004). Therefore, Good reading light keeps the reader alive and strengthens the book connection. Lighting is the key trigger that visually makes the reader comfortable (Brown et al., 2017). The crowded reading area, the social gathering area and the private reading rooms are three different spaces in the academic library with different usage and different daylight distribution (Gregg D. Ander, 2003).

- Crowded reading space: have elements, as long wooden tables and decorative lighting, implement quiet traditional work (Foster, 2010). Furthermore, Freeman (2005), claims that a large majority of students still regard the crowded reading room as their favorite space in the library. Wang and Boubekri (2010) noticed that most people decide to sit close or around the sun area, even though some people placed their desk back to the window and didn't have a direct view of the outside. For any library activities involving visual tasks such as reading and writing, the average value is about 500 lx, which ranges from 300 to 750 lx to allow visual comfort for the user (Carla Balocco, 2008).

- The private reading space: a vital part of the academic library as the desire for quiet, meditative study is as strong as ever and the absence of quiet space within the library is often associated with a common student complaint (Suarez, 2007). also deduced that, in relation to the rest of the room, the brightness of the work area also influences the amount of time spent in one position in the library and the reading performance (Kilic \& Hasirci, 2011). In addition, in dimmer lighting, people are less considerate of closer distances and seem to need more space in the corners compared to the room centers (Othman \& Mazli, 2012).

- Social gathering space: Daylight has a huge effect on the productivity and performance of the user in the library not only in reading and concentration but also in socializing. Results in studies examining the relationship between daylight and social behaviour showed that daylight satisfaction in social gathering spaces was related to window preference, ventilation, mood, view of the outside environment and for temporal data, day-time, and room appearance (Perera \& Swaris, 2017).

\section{Research Method}

This research adopts a mixed method approach where both qualitative and quantitative methods will be distributed into four levels. These levels were deduced from analyzing the literature review data to conduct a checklist (matrix) to be used by the researcher to identify the efficient strategies of daylight for enhancing the users' comfort in different spaces in academic libraries. the first level is analyzing the basics of daylight strategies that affects how daylight penetrate through the space. The second level is discussing the key aspects pertaining to users' visual and psychological comfort according to daylight aspects. The third level is studying certain spaces in academic libraries whether it is private reading space, group study space, or a social space to identify its different usage, daylight distribution, and impact on student perception and comfort. All the levels will be incorporated and filled in a checklist (matrix) that every dimension is sub dimensioned and supported with visual photographs for each type of daylight strategies. The last level is filling the checklist (matrix) according to the literature review data to identify as set of efficient daylight strategies for each space according to user comfort. 

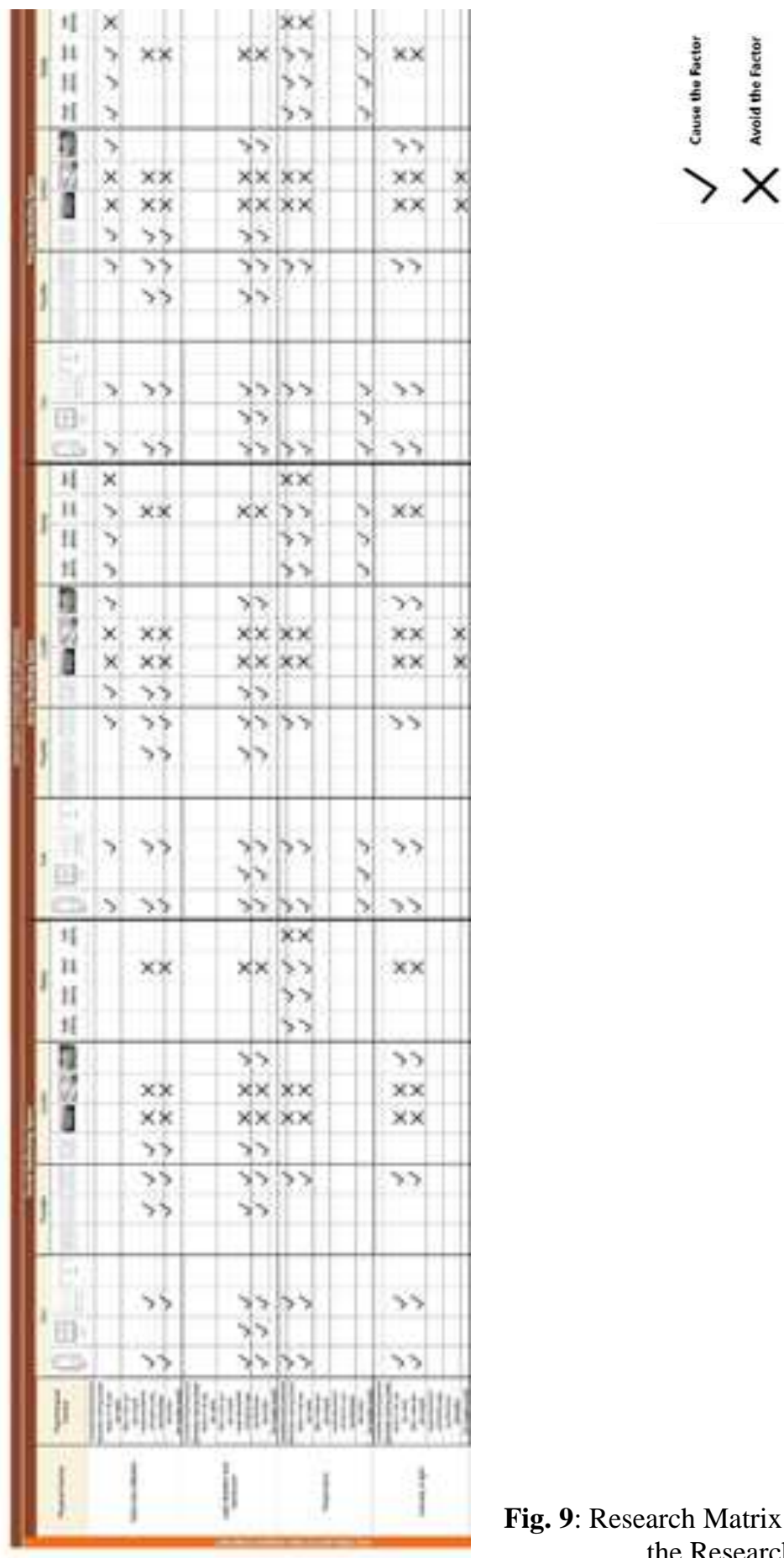

Fig. 9: Research Matrix by the Researcher 


\section{Discussion and Results}

In previous studies, there was no clear application of preceding integration. Recommended earlier studies determine the effects of daylight on human comfort without suggesting any design strategies for enhancing daylight in specific spaces. The contribution of this study proposes a design matrix form studies of the literature review that could be used by the researcher or the designer to reach efficiency in using daylight strategies to enhance the users' comfort in different spaces in academic libraries. the research result is divided into three parts which are the main library spaces and each space has different usage, needs, and daylighting strategies to reach users' visual and psychological comfort These three parts are:

- Social gathering space: it is a very critical area in the library as it gathers all college students with various needs. Therefore, it needs a special design of daylight to enhance the mood and visual performance of the users. It is ideal to use large vertical window with 1:2 proposition to have a good light direction and relation with the outdoor environment. Also, the windows ought to have shading devices or shelves to control the glare and use triple glazing for controlling solar heat and temperature in the indoor space. The spatial organization of the space should be close or around the sun area. Vertical windows are needed in this space as users need to have a connection with the outdoor environment as it affects the over all mood and cause the user to feel more active and alive.
- Private reading space: it is a unique space in the library with various needs as certain users do not prefer to read in daylighted zones other rather spend more time around the sun area. Also, daylighting in this space affects the overall reading performance and visual comfort. It is proposed to use Clerestory Windows, monitor skylight, or top vertical windows with 1:1 proportion to avoid glare and have an efficient light intensity for reading also allow some areas to be dimmed for users who do not prefer to read in daylight. Use triple glazing to control solar transmission and temperature. The spatial organization is placed in daylighted and dimmed areas to allow the user to choose the preferred location for establishing visual and psychological comfort. This type of daylight strategies is needed in this space as according to studies, users tend to feel more private in low light areas so using vertical openings in not required.

- Group reading space: majority of students consider the crowded reading area as their favorite space in the library. Most users decide to sit close or around the sun area, even though some users prefer to place their desk back to the window disregarding the direct view of the outside. It is preferred to use a mixed opening in this area as the outside view is important also an efficient daylight is needed. Therefore, it is advised to use vertical windows with shelves or baffles while using clerestory Windows or monitor skylight, both in 1:1 proportion to avoid glare and 
establish good intensity of natural light. Also, triple glazing is needed to control the solar heat form daylight and temperature side effects. Two types of openings are required in the is space as user need to feel visually comfortable and also have a connection with the surrounding environment.

\section{Conclusion}

Many of the current university libraries in Egypt lack the presence of efficient daylighting strategies and neglecting how daylight affects the students' comfort and university life experience. University libraries are one of the most important places that offer knowledge, services, study environment and social life. Recent researches studied the relationship between daylight and spaces and how it affects the users' comfort, satisfaction and performance in general without determining any design strategies or methods for efficient daylight. However, few researches managed to focus on university libraries and studied how it could affect the visual comfort, interaction with the surrounding and satisfaction in the space and determined the impact of daylight on human comfort from the existing design without determining the efficient way to integrate daylight into the library spaces. Therefore, this paper attempts to identify a set of efficient design strategies for daylight existing academic libraries in Egypt to enhance the users' visual comfort, psychological condition, and interaction with the surrounding in private reading space, group study space, or a social space using checklist (matrix) to measure the efficiency of the existing or proposed daylight design and how it affects visual and psychological comfort in certain spaces in academiclibraries.

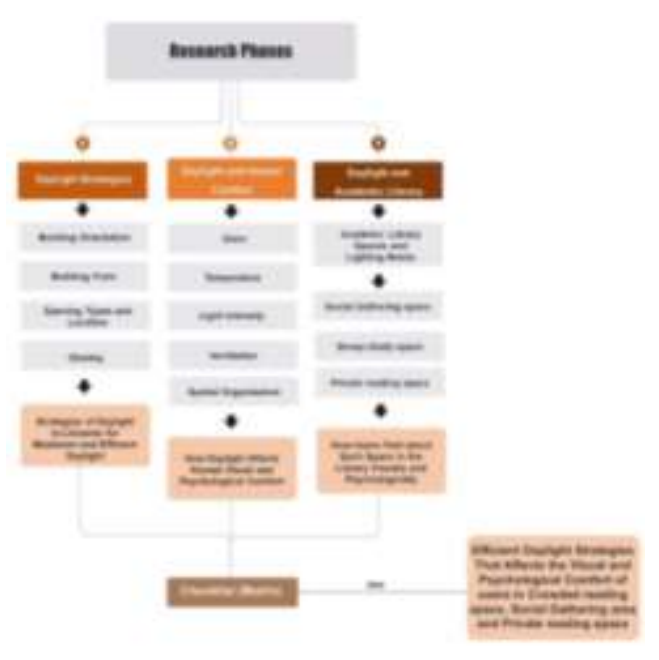

\section{Recommendations}

Academic library spaces in which different tasks are carried out at the same time must be

Fig. 13: Research Phases

well designed regarding daylight strategies. Furthermore, there are no clear strategies in place to date that outline the different library social setting and possible daylight strategies that could be implemented to correspond to each social setting in the library space. However, uncontrolled daylight brings visual, psychological discomfort and negative interaction to the user. This research recommends a various design strategies to avoid the discomfort accruing due to uncontrolled daylight to enhance the users' comfort in different spaces in academic libraries. 
Table 2. Recommended Design Strategies to Enhance the Uses' Comfort in Each space

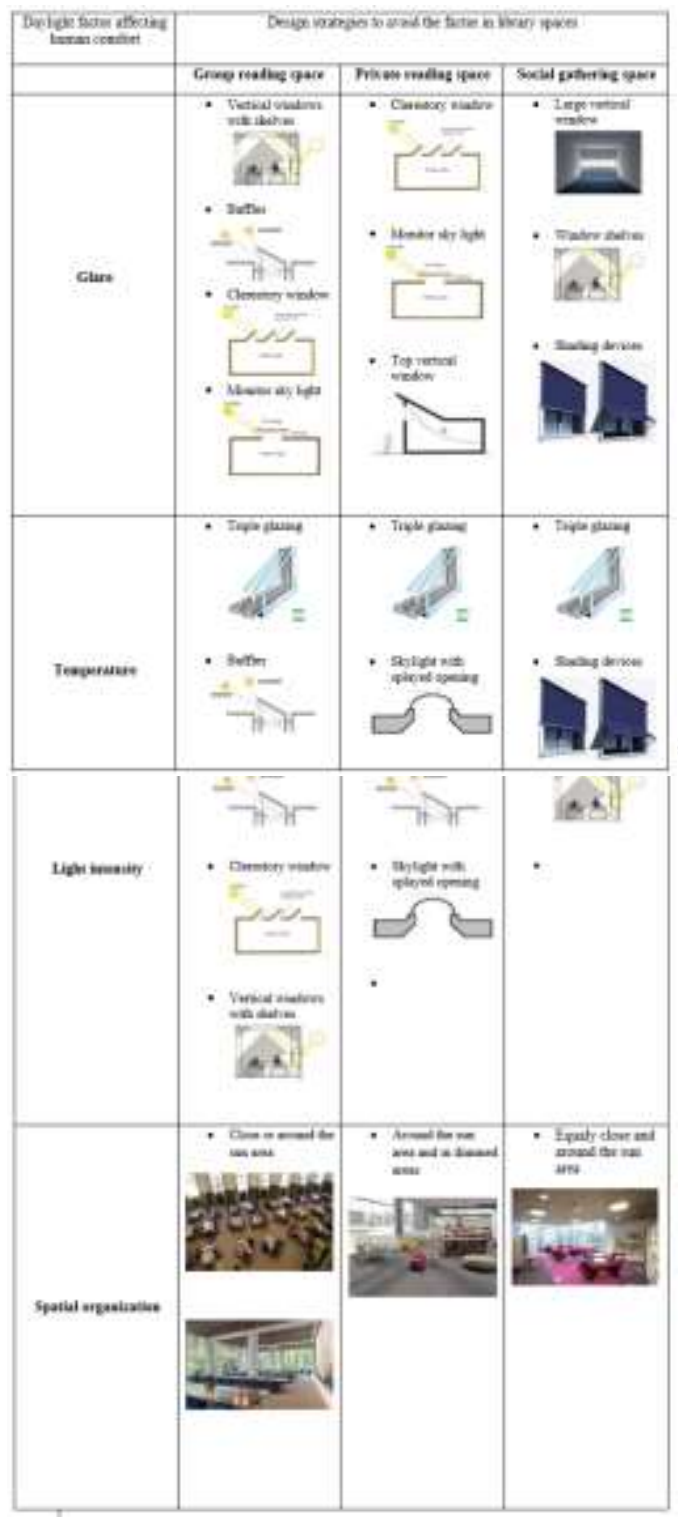

\section{References}

1. Brons, J. (2004). Daylight Dividends Case Study: Harmony Library, Fort Collins, Colorado. 14.

2. Brown, K., Malenfant, K. J., \& Association of College and Research Libraries. (2017). Academic library impact on student learning and success: findings from assessment in action team projects. April, 28. http://www.ala.org/acrl/sites/ala.org.acrl/file s/content/issues/value/findings_y3.pdf\%0A www.acrl.ala.org/value

3. Bertram W. Wells, "Subjective Responses to the Lighting Installations in a Modern Office Building and Their Design Implications", Environment and Behavior 14/3 (1965): 271-298.

4. Boyce, P., Hunter, C. and Howlett, O. (2003) The Benefits of Daylight through Windows, Lighting Research Center, Rensselaer Polytechnic Institute.

5. Cunningham, Heather V, \& Tabur, Susanne. (2012). Learning space attributes: reflections on academic library design and its use. Journal of Learning Spaces, 1(2), 6 . http://libjournal.uncg.edu/index.php/jls/artic le/viewFile/392/287

6. Darrell L. Butler \& Paul M. Biner, "Effects of Seating on Window Preferences and Factors Associated with Those Preferences", Environment and Behavior 21 (1989): 17-31.

7. Dean, E. T. (2005). Daylighting Design in Libraries. Libris Design Project, 23.

8. Essays, UK. (November 2018). Factors Affecting Human Comfort In Buildings. Retrieved from https://www.ukessays.com/essays/engineeri ng/human-comfort-in-the-internalenvironment.php?vref $=1$

9. Feinberg Sandra 'James R. Keller, A. (2010). Designing Space for Children and Teens in Libraries and Public Places. America Library Association. https://books.google.com.eg/books?id 10. Gregg D. Ander. (2003). Daylighting Performance and Design. john weily \& sons, inc.

https://books.google.com.eg/books?hl=en\&l $\mathrm{r}=\& \mathrm{id}=\mathrm{RBMHD} 5 \mathrm{Wk} 6 \mathrm{LwC} \& \mathrm{oi}=$ fnd \&pg $=\mathrm{I}$ A1\&dq=related:WWnBEl7qJxMJ:scholar.g oogle.com/\&ots=sx_QZg7seT\&sig=tn_O6S 
vnEZRnqg96Us3IUO4Yf9E\&redir_esc=y\# $\mathrm{v}=$ onepage $\& \mathrm{q} \& \mathrm{f}=$ false

11. Grimaldi, S., Partonen, T., Saarni, S. I., Aromaa, A., and Lönnqvist, J. (2008) Indoors illumination and seasonal changes in mood and behavior are associated with the health-related quality of life. Health and Quality of Life Outcomes, 6, 56. doi: 10.1186/1477-7525-6-56.

12. HOURANI, May, and HAMMAD, Rizeq (2012). Impact of daylight quality on architectural space dynamics: Case study: City Mall--Amman, Jordan. Renewable and Sustainable Energy Reviews, 16 (6), 35793585 .

13. John E. Flynn, Terry J. Spencer, Osyp Martyniuk \& Clyde Hendrick, "Interim Study of Procedures for Investigating the Effect of Light on Impression and Behaviour", Journal of IES (1973): 87-94.

14. Judith Heerwagen \& Dean Heerwagen, "Lighting and Psychological Comfort", Environment and Behavior 19/6 (1986): 695-721.

15. Kilic, D. K., \& Hasirci, D. (2011). Daylighting Concepts for University Libraries and Their Influences on Users' Satisfaction. Journal of Academic Librarianship, 37(6), 471-479. https://doi.org/10.1016/j.acalib.2011.07.003 16. Klain Gabbay, L., \& Shoham, S. (2019). The role of academic libraries in research and teaching. Journal of Librarianship and Information Science, 51(3), 721-736. https://doi.org/10.1177/0961000617742462

17. Lawrence Berkeley National Laboratory (2009). Temperature and school work performance. Berkeley, CA: Lawrence Berkeley National Laboratory, Retrieved on July 25, 2012, from http://www.iaqscience.lbl.gov/performancetemp-school.html

18. Lam, W. (1977) Perception and Lighting as Formgivers for Architecture, McGrawHill.

19. Lisa K. Block \& Garnett S. Stokes, "Performance and Satisfaction in Private versus Nonprivate Work Settings", Environment and Behavior 21 (1989): 277.
20. Li, L. H., Wu, F., \& Su, B. (2018). Impacts of Library Space on Learning Satisfaction - An Empirical Study of University Library Design in Guangzhou, China. Journal of Academic Librarianship, 44(6), 724-737. https://doi.org/10.1016/j.acalib.2018.10.003 21. Ludwig L, Starr S. Library as place: results of a delphi study. Journal of the Medical Library Association : Jmla. 2005 Jul;93(3):315-326.

22. Malman D. (2005). Lighting for Libraries. U.S. Institute of Museum and Library Services, 19. https://hosting.iar.unicamp.br/lab/luz/ld/Arq uitetural/diversos/Lighting for Libraries.pdf 23. Nirma swaris, \& Perera, N. (2017). GOOD READING LIGHT: VISUAL COMFORT PERCEPTION AND DAYLIGHT INTEGRATION IN LIBRARY SPACES. Proceedings of the 10thInternational Conference of Faculty of Architecture Research Unit (FARU), University of Moratuwa, Sri Lanka, 1, 336348.

24. Othman, A. R., \& Mazli, M. A. M. (2012). Influences of Daylighting towards Readers' Satisfaction at Raja Tun Uda Public Library, Shah Alam. Procedia - Social and Behavioral Sciences, 68(October), 244-257. https://doi.org/10.1016/j.sbspro.2012.12.224 25. Perera, N., \& Swaris, N. (2017). Good Reading Light: Visual Comfort Perception and Daylight Integration in Library Spaces. April,

$0-12$.

https://www.researchgate.net/publication/32 1719388

26. Peter Tregenza and Michael Wilson. (2011). Daylighting architecture and lighting design.

27. Phillips, D. (2004). Daylighting Natural Lightin Architecture.

28. Qahtan, A. (2017). Illumination \& Acoustics. 55 . https://www.slideshare.net/AbdultawabQaht an/daylighting-77804592

29. Rea, M.S. (2000) The IESNA Lighting Handbook: Reference and application, New York: Illuminating Engineering Society of 
30. Reinhart, C. (2014) Daylight Handbook I 31. Sufar, S., Talib, A., \& Hambali, H. (2012). Towards a Better Design: Physical Interior Environments of Public Libraries in Peninsular Malaysia. Procedia - Social and Behavioral Sciences, 42(July 2010), 131143.

https://doi.org/10.1016/j.sbspro.2012.04.174 32. Yang, Z. (2017). Research on natural lighting in reading spaces of university libraries in Jinan under the perspective of energy-efficiency. IOP Conference Series: Earth and Environmental Science, 94(1). https://doi.org/10.1088/1755-

1315/94/1/012181

33. Zain-Ahmed, Sopian, K., Othman, M.Y.H., Sayigh, A.A.M. \& Surendran, P. N. (2002). Daylighting as a passive solar design strategy in tropical buildings: A case study of Malaysia. Energy Conversion and Management , 43, 1725-1736. 


\title{
تحسين راحة المستخدمين في المكتبات الجامعية الموجودة في مصر
}

\section{من خلال استراتيجيات ضوء النهار}

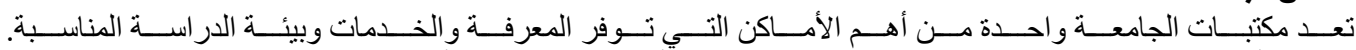

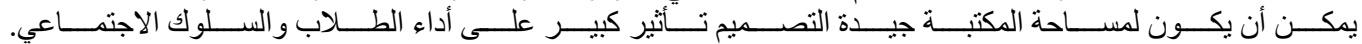

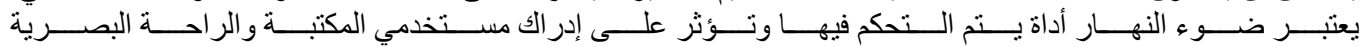

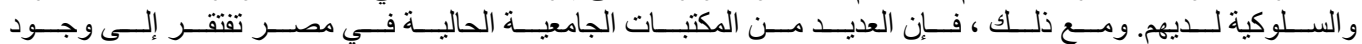

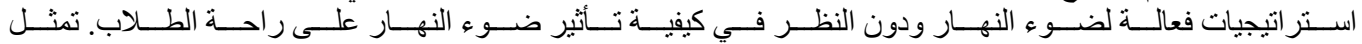

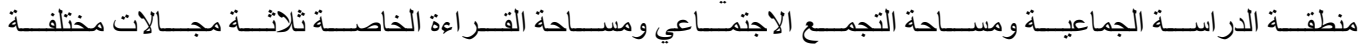

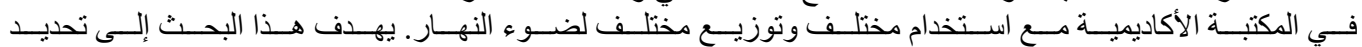

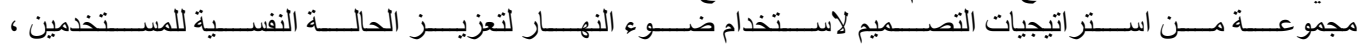

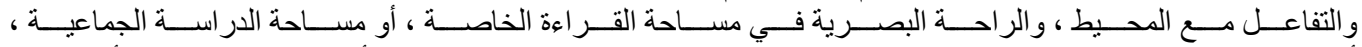

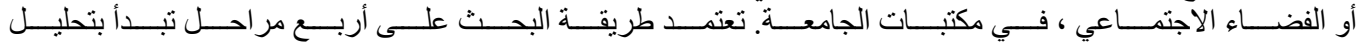

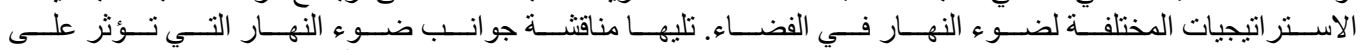

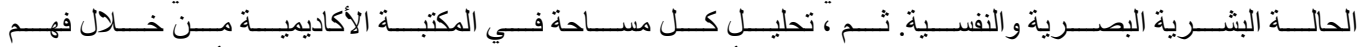

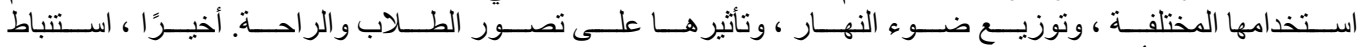

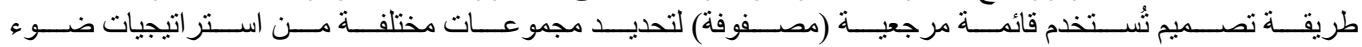

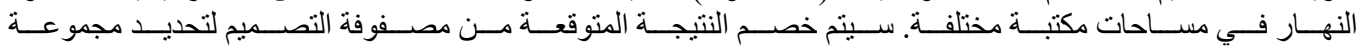

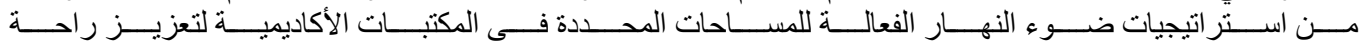

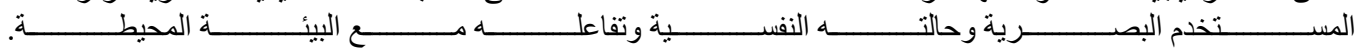

